\title{
Biological Management of Grey Leaf Blight (Pestalotia anacardii) of Mango (Mangifera indica)
}

\author{
V. A. Patil ${ }^{1}$, B. P. Mehta ${ }^{2}$ and A. J. Deshmukh ${ }^{3}$
}

${ }^{1}$ Dept. of Plant Pathology, Soil and Water Management Research Unit, Navsari Agricultural University, Navsari (396 450$)$, India ${ }^{2}$ Dept. of Plant Pathology, Aspee College of Horticulture and Forestry, Navsari Agricultural University, Navsari (396 450), India

${ }^{3}$ Dept. of Plant Pathology,College of Agriculture, Navsari Agricultural University, Waghai (394 730), India

\section{Corresponding Author}

V. A. Patil

e-mail:vapatil_swm@nau.in

\author{
Article History \\ Article ID: IJEP0301 \\ Received in $08^{\text {th }}$ April, 2019 \\ Received in revised form $28^{\text {th }}$ April, 2019 \\ Accepted in final form 18 ${ }^{\text {th }}$ May, 2019
}

\begin{abstract}
Mango is one of the important fruit crops grown extensively in Gujarat. Mango trees were found severely affected by grey leaf blight disease (Pestalotia anacardii) at Horticulture farm of Navsari Agricultural University, Navsari. So, present investigation was carried out to study the biological management measures against the disease under greenhouse conditions on cultivar Kesar. Among the various antagonists studied, P. fluorescens, T. viride and T. harzianum were found promising as potential biocontrol agents against grey leaf blight of mango.
\end{abstract}

Keywords: Antagonists, grey leaf blight, Kesar, Pestalotia anacardii

\section{Introduction}

Mango is known as king of fruits not only in the Indian subcontinent but also the world over. Botanically, mango belongs to the genus Mangifera which finds its origin in South-East Asia and Indo-Myanmar regions. The genus, Mangifera comprises of 41 species (Mukherjee, 1985), however, total reported species now stands at 39 (Mukherjee and Stolon, 1989). All the edible cultivars of mango represent the species indica which originated in the Indian sub-continent. Looking to the seriousness of the disease and economic importance of the crop in this area, present investigations were undertaken to study the behaviour of the disease and to generate necessary information for suitable biological management measures to minimize crop losses.

\section{Materials and Methods}

Eight known antagonists viz., Trichoderma viride Pers.Fr (Navsari isolate), Trichoderma harzianum Rifai (Navsari isolate), Trichoderma longibrachyatum (Pune isolate), Aspergillus niger (IARI isolate), Pseudomonas fluorescens (Navsari isolate), Pseudomonas aeruginosa (Waghai isolate), Chaetomium globosum Kunze (IARI isolate) and Bacillus subtilis Ell. (Navsari isolate) were tested by dual culture technique (Dennis and Webster, 1971), pathogen at periphery and pathogen at centre (Asalmol et al., 1990) methods in vitro against $P$. anacardii.
On the basis of good performance of fungal and bacterial antagonists under in vitro conditions, effective antagonists were evaluated in the pot trial against grey leaf blight of mango under green house condition. Variety Kesar was used for the study. Five treatments of effective antagonists with one check were laid out in completely randomized design. One year healthy mango seedlings with 8-10 leaves were selected and inoculated with P. anacardii @ $2 \times 10^{6}$ spores $/ \mathrm{ml}$ by pin pricking method. There were three repetitions. Seven days after inoculation of the pathogen and its successful development, the antagonists $T$. viride, $T$. harzianum, $B$. subtilis, P. fluorescens and P. aeruginosa were sprayed @ $2 \times 10^{8} \mathrm{cfu} / \mathrm{ml}$ each separately.

Observations on per cent disease intensity (PDI) were recorded at seven days interval after application of antagonists and disease ratings were recorded on the basis of grade scale (0-5) given by Patel (1988) as mentioned below:

\begin{tabular}{ll}
\hline Scale & Description \\
\hline 0 & Completely healthy - No spots \\
1 & 1 to $10 \%$ area of leaf infected \\
2 & 11 to $25 \%$ area of leaf infected \\
3 & 26 to $50 \%$ area of leaf infected \\
4 & 51 to $75 \%$ area of leaf infected \\
5 & More than $75 \%$ area of leaf infected and \\
\hline
\end{tabular}


PDI = ( $\Sigma$ Ratings of infected leaves observed/No. of leaves observed $x$ Maximum disease score) $\times 100$

The data were analyzed, interpreted and the per cent disease control was worked out.

\section{Results and Discussion}

The hazardous effect of chemicals used in plant disease management has diverted plant pathologists to find out the alternative method with little or no adverse effect on environment. Notable success of disease control through use of antagonistic microorganisms in the laboratory, green house and field had been achieved during past several years and based on this information; there is a possibility of developing biological control of plant disease under field conditions.

Antagonists viz., T. viride, T. harzianum, T. longibrachyatum, $A$. niger, $P$. fluorescens, $P$. aeruginosa, $C$. globosum and $B$. subtilis were tested in vitro by three different methods for their antagonism against $P$. anacardii. Among them, best antagonists viz. $P$. fluorescens, $T$. viride, $T$. harzianum, $P$. aeruginosa and $B$. subtilis were checked for their antagonism on one year old mango seedlings of cultivar Kesar under green house condition

The results presented in Table 1 revealed that all the antagonists studied in pot culture against $P$. anacardii causing grey leaf blight of mango were found significantly superior over control (Plate 1). Among them, minimum per cent disease intensity (11.24\%) was observed in $P$. fluorescens followed by $T$. viride (14.21\%), T. harzianum (21.12\%), $P$. aeruginosa (26.13\%) and B. subtilis (29.89\%). Maximum per cent disease control (74.07\%) was observed in $P$. fluorescens, which was found superior over rest of the treatments. Next best antagonist was $T$. viride with per cent disease control of $67.21 \%$ followed by $T$. harzianum (51.27\%). P. aeruginosa

Table 1: Effect of different antagonists against Pestalotia anacardii under greenhouse condition

\begin{tabular}{llcc}
\hline $\begin{array}{l}\text { Sl. } \\
\text { No. }\end{array}$ & Test organism & $\begin{array}{c}\text { Per cent } \\
\text { disease } \\
\text { intensity }\end{array}$ & $\begin{array}{c}\text { Per cent } \\
\text { disease } \\
\text { control }\end{array}$ \\
\hline 1. $\quad \begin{array}{l}\text { Trichoderma viride Pers. } \\
\text { Fr (Navsari isolate) }\end{array}$ & $\begin{array}{c}\text { 22.12* } \\
(14.21)^{* *}\end{array}$ & 67.21 \\
2. $\quad \begin{array}{l}\text { Trichoderma harzianum } \\
\text { Rifai (Navsari isolate) }\end{array}$ & $27.34(21.12)$ & 51.27 \\
3. $\quad \begin{array}{l}\text { Bacillus subtilis Ell. } \\
\text { (Navsari isolate) }\end{array}$ & $33.13(29.89)$ & 31.03 \\
4. $\quad \begin{array}{l}\text { Pseudomonas fluores- } \\
\text { cens (Navsari isolate) }\end{array}$ & $19.56(11.24)$ & 74.07 \\
5. $\quad \begin{array}{l}\text { Pseudomonas aerugi- } \\
\text { nosa (Waghai isolate) }\end{array}$ & $30.73(26.13)$ & 39.71 \\
6. Control (only P. anacar- & $41.16(43.34)$ & - \\
\hline & & & \\
\hline
\end{tabular}
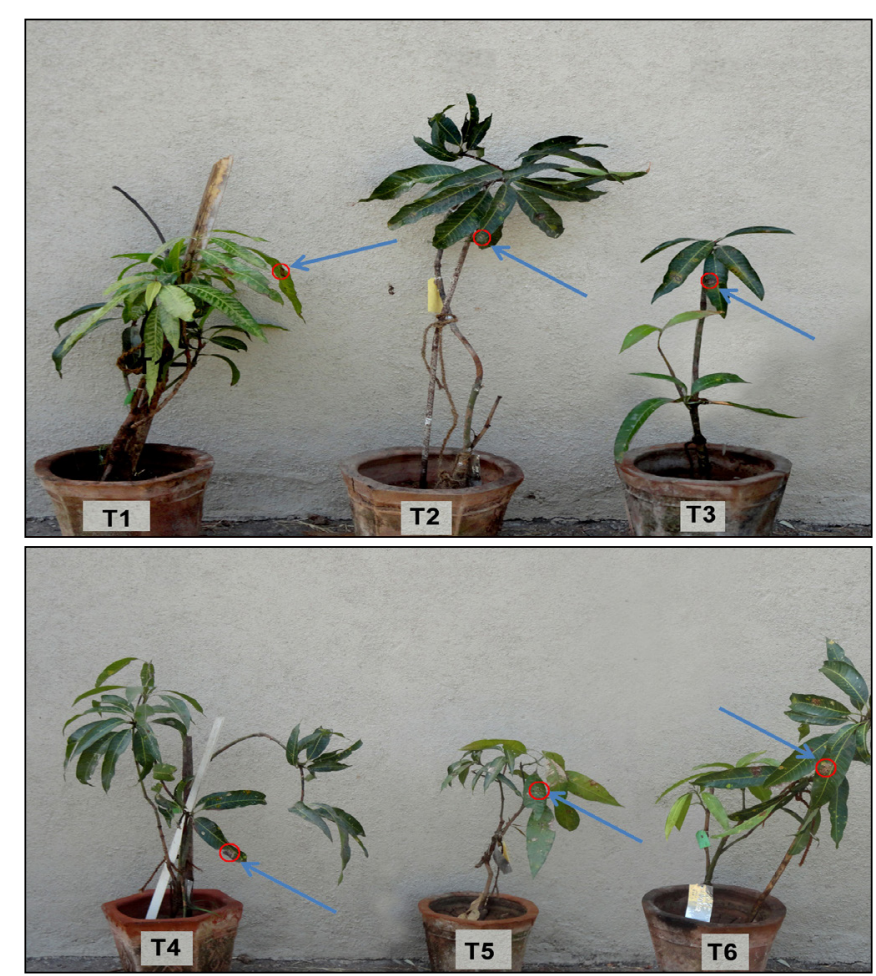

$\mathrm{T}_{1}$ : Pseudomonas fluorescens; $\mathrm{T}_{2}$ : Trichoderma viride; $\mathrm{T}_{3}$ : Trichoderma harzianum; $\mathrm{T}_{4}$ : Pseudomonas aeruginosa; $\mathrm{T}_{5}$ : Bacillus subtilis; $\mathrm{T}_{6}$ : Control (only pathogen inoculation)

Plate 1: Effect If a tagonists against $P$. anacardii in green house was found to be moderately effective with per cent disease control of $39.71 \%$. B. subtilis was found least effective against grey leaf blight disease of mango with per cent disease control of $31.03 \%$, respectively. This data clearly indicates the effectiveness of $P$. fluorescens, $T$. viride and $T$. harzianum against $P$. anacardii and can prove as promising biocontrol agents against grey leaf blight of mango.

The results are in close proximity with Ping et al. (2007) and Karthikeyan et al. (2002), wherein they observed antagonistic effect of Trichoderma sp. against Pestalotiopsis sp. isolated from pine trees and coconut, respectively. Biocontrol agents Trichoderma sp. and Pseudomonas sp. were found inhibitory against Pestalotiopsis spp. causing grey blight disease of tea in nurseries (Sanjay et al., 2008). B. subtilis NCIB 3610 considerably reduced the disease symptoms on mango produced by Pestalotiopsis mangiferae (Okigbo and Osuinde, 2003).

\section{Conclusion}

Fungal and bacterial antagonists were studied under greenhouse condition against grey leaf blight disease of mango on cv. Kesar. Among all the antagonists screened against $P$. anacardii, $P$. fluorescens, $T$. viride and $T$. harzianum were found most effective with per cent disease control of $74.07,67.21$ and $51.27 \%$, respectively. 


\section{Acknowledgement}

The authors express their gratitude to The Director of research, Dean P.G. Studies, Navsari Agricultural University, Navsari, Gujarat for providing necessary facilities during the present investigations. Authors are also thankful to ITCC. IARI, New Delhi for identification of the pathogen.

\section{References}

Asalmol, M.N., Sen, B., Awasthi, J., 1990. Role of temperature and $\mathrm{pH}$ in antagonism of Aspergillus niger and Trichoderma viride against Fusarium solani. In: Proc. All India Phytopathol. Soc., (West Zone), M.P.A.U., Pune, 11-13.

Dennis, C., Webster, J., 1971. Antagonistic properties of species groups of Trichoderma III hyphal interaction. Trans. Brt. Mycol. Soc. 57, 363-369.

Karthikeyan, M., Sarala, L., Karunanithi, K., Rajarethinam, S., 2002. Control of leaf blight disease of coconut in Tamil Nadu. Indian Coconut 32, 6-7.
Mukherjee, S.K., 1985. Distribution of species on the mango genepool, IBPGR, FAO, Rome, 112.

Mukherjee, S.K., Stolon, Van D.H., 1989. Mango germplasm- A global perspective 231, 75-82.

Okigbo, R.N., Osuinde, M.I., 2003. Fungal leaf spot diseases of mango (Mangifera indica L.) in Southeastern Nigeria and biological control with Bacillus subtilis. Plant Protection Science 39, 70-77.

Patel, R.B., 1988. Studies on grey leaf spot of mango Pestalotiopsis mangiferae (Henn.) Steyaert and its control. M.Sc. Thesis, G.A.U., Navsari, 12-71.

Ping, J., Xiaoqin, W., Jianren, Y., Jiangmei, S., 2007. Screening of antagonistic microbes to two kinds of pine trees pathogens. Journal of Nanjing Forestry University (Natural Sciences Edition) 31, 59-62.

Sanjay, R., Ponmurugan, P., Baby, U.I., 2008. Evaluation of fungicides and biocontrol agents against grey blight disease of tea in the field. Crop Protection 27, 689-694. 